\title{
Yaratıcı Kişilik Özellikleri Ölçeği: Güvenilirlik ve Geçerlik Çalışması ${ }^{1}$
}

\author{
Feyzullah Şahina ${ }^{*}$, Şahin Danışman ${ }^{b}$ \\ a,bDüzce Üniversitesi, Eğitim Fakültesi, Düzce
}

\begin{abstract}
Öz
Bu çalışmanın amacı, kültüre özgün bir takım yaratıcı kişilik özelliklerinin değerlendirilmesine yönelik bir ölçme aracı geliştirilmesidir. Ölçeğin yapı geçerliğini incelemek için yapılan Açıklayıcı Faktör Analizi sonucunda, 17 maddeden oluşan dört faktörlü bir yapı elde edilmiştir. Ortaya çıkan yapı bir başka örneklem grupta test edilmiştir. Doğrulayıcı Faktör analizi sonucu ortaya çıkarılan model doğrulanmıştır $\left(\chi^{2} / S d=2.332\right.$, RMSEA $=.04$, SRMR $=.04$, GFI= .97, CFI= .95). Ölçeğin alt faktörleri için Cronbach alfa iç tutarlılık katsayısı 60 ile .65 aralı̆̆ında hesaplanmıştır. Ölçek geneli ise .67 'dir. Ölçek alt boyutlarının ayırt edici geçerliliği alt-üst dilim grup ortalamaları farkına dayal olarak incelenmiştir. Analizler sonucunda, alt ve üst \%27'lik dilimlerin puanları arasında anlaml bir farklllık olduğu tespit edilmiştir $\left(t_{(240)}=-127.911,-\right.$ 97.235, -118.358, -81.935 ve -125.503, $p<.01)$. Bu sonuçlar Yaratıcı Kişilik Özellikleri Ölçeğinin Türk kültüründe geçerli ve güvenilir bir ölçme aracı olarak kullanılabileceğini göstermektedir.
\end{abstract}

Anahtar Kelimeler: Yaratıcı kişilik özellikleri, amaç yönelimlilik, içsel motivasyon, kendine güven, risk alma.

\section{Creative Personality Traits Scale: Reliability and Validity Study}

\section{Abstract}

This study aims to develop a scale to determine a number of culture specific creative personality traits. After the conductment of Exploratory Factor Analysis to test the construct validity, a four factor structure with 17 items have been obtained. This structure has been tested on a different set of sample. The obtained model has been validated through Confirmatory Factor Analysis $\left(\chi^{2} / S d=2.332, R M S E A=.04, S R M R=.04, G F I=.97, C F I=.95\right)$. Cronbach alpha coefficients for internal consistency have been calculated between .60 and .65 for the subscales, while it has been found to be .67 for the whole scale. The discriminant validity of subscales has been examined based on the differences of mean scores of lower and upper level groups. A significant difference between the scores of lower and upper level groups has been discovered ( $t_{(240)}$ $=-127.911,-97.235,-118.358,-81.935$, and $-125.503, p<.01)$. These findings suggest that Creative Personality Traits Scale is a valid and reliable measurement tool in Turkish culture.

Keywords: Creativity personality traits, task oriented, internal motivation, self-confidence, risktaking.

\footnotetext{
${ }^{1}$ Bu çalışmanın bir kısmı, 24-26 Ağustos 2016 tarihleri arasında Bangkok/ Tayland'da, düzenlenen VII. Rajamangala University of Technology International Conference' da sözel bildiri olarak sunulmuştur.

*Yazısma adresi. Email:feyzullahsahin@duzce.edu.tr
} 


\section{GİRIŞ}

Yaratıcı düşünme becerisi, insanların doğuştan getirdiği ve insanlarda farklı düzeylerde ortaya çıkabilen bir özelliktir. Her koşulda doğrusal olmayan bir dizi etkileşime bağlı ortaya çıkmaktadır (Amabile, 1983, 1996; Sternberg ve Lubart, 1991). Örneğin, sanat alanında yaratıcı bir yanıtın ortaya çıkmasında sinerji oluşturan nevrotik kişilik yapısı gibi bir özellik, bilim gibi bir başka alanda tam tersi sonuçları yol açabilmektedir. Bireyin yaratıcı yanıtlarının ortaya çıkmasında düşünsel ve düşünsel süreçleri şekillendiren aile ortamı, okul sistemi, kişilik yapısı, kültürel yapı vb. bir takım çevresel etmenler rol oynamaktadır. Söz konusu etmenler doğuştan gelen özellikler üzerinde, "Kartopu etkisi yaparak" gelişmesini sağladığı gibi tam tersine sönmesine de yol açabilmektedir.

Yaratıcılık, günümüzde farklı nedenlerle birçok disiplin alanının artan bir ivme ile ilgisini çekmektedir. Guilford'un (1966) Amerika Psikologlar Derneğinde yaptığı geniş yankı bulan konuşması bir dönüm noktası kabul edilir. Taylor, 1988'de yapmış olduğu bir derlemede güncel 60 farklı yaratıcılık tanımının olduğunu saptamıştır (Furnham vd., 2008). Bundan yaklaşık 22 yıl sonra yapılan bir başka çalışmada ise bu sayı 101'e çıkmıştır (Aleinikov, Kackmeister ve Koening, 2000, akt. Terrefinger, Young, Selby ve Shepardson, 2002). Söz konusu tanımlarda öne çıkan iki vurgu ise başarı ve potansiyeldir (Jauk, Benedek, Dunst ve Neubauer, 2013). Başarı, daha çok ürüne işaret ederken, potansiyel en yalın hali ile yeni ve uygun bir şeyler üretme yeteneğine işaret etmektedir (Sternberg, O'Hara ve Lubart, 1997). Yaratıcı düşünme potansiyeli, rraksak düşünme ve yaratıcılığın duyuşsal boyutu olarakta nitelendirilen yaratıcı kişilik özellikleri bağlamında iki alt kategori altında incelenmektedir.

Guilford (1967, akt. Sternberg, Jarvin ve Grigorenko, 2011) ortaya atmış olduğu Zeka Yapı Modelinde yaratıcı düşünme potansiyeli, ıraksak düşünme becerisi olarak açıklanmıştır. Bu açıklama sonraki araştırmacılarca izlenmiştir. Yaratıcılığı destekleyici kişilik özellikleri ise güncel araştırmalarda kişilik özelliklerinin açılanmasına yönelik kuramlar veya bireysel farkları ortaya çıkaran özellikler kapsamında açıklanmaya çalışılmaktadır.

Iraksak düşünme becerileri ile bireylerin yaratıcılığı destekleyici kişilik özellikleri “Beş büyük kişilik özelliği” kapsamında bir grup araştırmada incelenmiştir. Bu çalışmalardan ilki Soldz ve Vaillant (1999) tarafından 163 erkekle sürdürmüş olan 45 yıllık boylamsal araştırmasıdır. Söz konusu çalışmada deneyimlere açıklık ile pozitif $(r=.40)$, uyumluluk ile negatif $(r=-.27)$ bir ilişki saptanmıştır. Diğer üç kişilik özelliğinde ise anlamlı bir ilişki ortaya çıkmamıştır. Feist'in (1998) bilimsel ve sanatsal yaratıcılık alanında hazırlanmış olan seksen üç çalışmayı dahil ettiği bir meta analiz araştırmada ise dışa dönüklük, deneyimlere açıklık ve duygusal denge ile yaratıcılık arasındaki pozitif, uyumluluk ve sorumluluk ile arasında negatif bir korelasyon tespit edilmiştir. Furnham ve meslektaşları (2008), Furnham ve Bachtiar (2008), McCrae ve Costa (1997) ile Sanchez-Ruiz ve meslektaşları (2011) tarafından sürdürülen araştırmalarda ise ortak bulgu olarak yaratıcılık ile deneyimlere açıklık ve dişa dönüklük arasında anlamlı bir ilişki olduğu ortaya konulmuştur. 


\subsection{Yaratıcı Kişilerin Özellikleri}

Yaratıcı düşünme becerilerinin açıklanmasına yönelik ilk bilimsel çalışmalar, Galton'un (1869/1962, akt. Batey ve Furnham, 2006) "Hereditary Genius" eseri ile Londra Okulu'nun yaratıcı düşünmenin temel ölçütlerinden olan akıcılığın açıklanmasına yönelik araştırmalara kadar dayanmaktadır (Hargreaves, 1927, akt. Batey ve Furnham, 2006). Yaratıcı bireylerin akranlarında farklılığına ilişkin alan yazında oldukça geniş bir literatür vardır. Barron ve Harrington (1981) araştırması ile Feist (1999) ve Sak'ın (2016) derlemeleri bu bağlamda örnek olarak verilebilir.

Barron ve Harrington (1981), 15 yıllık gözlem sonuçlarına dayalı olarak farklı alanlarda yaratıcılığı yüksek olan bireyleri ilgi alanları yaygın, içsel olarak motiveli, yüksek estetik kriterlere sahip, enerjik, risk alabilen, bağımsız karar verebilen, kendine güvenli, sorgulayıcı, farklı bakış açıları geliştirebilen bireyler olarak tanımlamıştır. Feist (1999) ise bir derleme çalışmada sanat ve bilim alanında yaratıcı başarısı yüksek olan bireylerin özelliklerini toparlamıştır. Bilim adamlarının yeni deneyimlere açık, daha gelenekçi, kendine güveni yüksek, öz - alg1 düzeyi yüksek, içsel yönelimli, hırslı, saldırgan, içsel yönelimli olduğunu bildirmiştir. Sanatçıların ise daha duyuşsal, durağan olmayan bir duygu durum hali, sosyal becerileri daha düşük ve bilim adamlarına göre grup tarafından daha az kabul gören bireyler olduğu belirlenmiştir. Sak'ın (2016) derleme çalışmasında da en sık bahsedilen özellikler orijinal düşünme, yüksek zekaya sahip olma, yaratıcı farkındalık, mantıksal ve sıradışı düşünme, gelişmiş sorgulama becerileri, bilgi ve tecrübe sahibi olma, bağımsız karar verme, risk alma, enerjik olma, meraklı olma, espritüel olma, bilinmeye karşı ilgi duyma, gelişmiş hayal gücü, estetik duyarlılık, açık görüşlülük, yalnız kalma ihtiyacı, sezgisel, duygusal ve gelişmiş etik değerlere sahip olma biçiminde özetlenmiştir.

\subsection{Problem durumu}

Bireylerin yaratıcı kişilik özelliklerinin değerlendirilmesinde başvurulan yöntemlerden birisi de öz-değerlendirme veya aday gösterme formlarıdır. Bu formların en önemli avantajı, kısa zamanda çok fazla bireye ilişkin veri toplanabilmesidir (Şahin ve Şahin, 2012, 2013). Yurt dışı alan yazında en sık kullanılan bu formlardan bazıları Gough'un Yaratıcı Kişilik Özellikleri Ölçeği, Kaliforniya Psikoloji Envanteri, Neo-PR Yaratıcı kişilik Özellikleri Ölçeği, Eysenck Kişilik Anketi, Minnesota Çok Yönlü Kişilik Envanteri biçiminde sıralanabilir.

Türkiye'de ise bireylerin yaratıcı kişilik özeliklerinin ölçümünde Yaratıcı Düşünme Becerisi Ölçeği (Aksoy, 2004), Sıfat Listesi (Savran, 1993), Kaufman Yaratıcılık Alanları Ölçeği Türkçe formu (KAYÖ-TR) (Şahin, 2016), ve Sıfatlara Dayalı Kişilik Testleri (Bacanlı, İlhan ve Aslan, 2009) en sık kullanılan testler arasında yer almaktadır. Yaratıcı Düşünme Becerisi Ölçeği tek bir alt faktöre sahip bir ölçme aracı olup, bu ölçek bireyin genel yaratıcılık özelliklerinin ölçülmesini hedeflemektedir. Sıfat listesi ise genel yaratıcılığı ölçmeye yönelik hazırlanmış, 300 sıfat içeren, 24 alt faktörden oluşan bir ölçme aracıdır. KAYÖ-TR akademik, bilimsel/ mekanik, sanatsal performans, öz/ günlük ve sanatsal yaratıcılık alt alanlarında oluşan alana özgü bir ölçme aracıdır. Ölçek toplamından genel yaratıcılığa ilişkin bir puan da elde 
edilebilmektedir. Sıfatlara Dayalı Kişilik Testi, sıfat çiftlerine dayalı olarak geliştirilmiş, duygusal dengesizlik / nevrotizm, dişadönüklük, deneyimlere açıklık, yumuşak başlılık, sorumluluk olarak isimlendirilen beş büyük kişilik özellikleri bağlamında ölçüm yapılmaktadır. İlk üç ölçme aracı uyarlama iken Sıfatlara Dayalı Kişilik Testi Türkiye örnekleminde geliştirilmiştir.

Yaratıcı kişilik özellikleri, bir önceki bölümde de değinildiği üzere oldukça geniş bir aralıkta bir takım davranışları içermektedir. Dolayısıyla, farklı madde havuzu ve yaklaşımlar ile geliştirilecek ölçme araçları konuya ilişkin daha detaylı bilgi edinilmesine yardımcı olacaktır. Bu bağlamda, bu çalışma yaratıcı kişilik özelliklerinin belirlenmesi amacıyla yürütülmüştür. Çalışmanın genel amacı, Türk kültürüne uygun bir takım yaratıcı kişilik özelliklerinin ölçümüne yönelik bir ölçme aracının geliştirilmesidir.

\section{YÖNTEM}

\subsection{Model ve Çalışma Grubu}

Araştırma tarama modeline dayalı olarak, Türkiye'deki yedi farklı ilde (Sakarya, Düzce, Eskişehir, Kütahya, Tokat, Zonguldak, Samsun) lise ve üniversitelere devam eden öğrenciler ile yürütülmüştür. Çalışmanın katılımcıları 2016-2017 eğitimöğretim yılında eğitimini sürdüren lise ve üniversite öğrencileridir. Katılımcıların seçilmesinde gönüllülük esas alınmış ve kolay ulaşılabilir örnekleme yoluyla seçilen katılımcılar araştırmanın örneklemini oluşturmuştur. Çalışma kapsamında toplamda 2061 öğrenciden veri toplanmıştır. Veri giriş öncesinde, eksik, hatalı ve özensiz doldurulan, veri girişinden sonra ise uç değer olduğu tespit edilen 291 ölçme aracı ayıklanmış, kalan 1770 öğrenciden elde edilen veriler ile analizler sürdürülmüştür.

Öğrencilerin, 1.020'si (\%57.63) lise, 750'si (42.37) üniversiteye devam etmektedir. Katılımciların 10'u (\%.6) 13, 210'u (\%11.9) 14, 289'u (\%16.30) 15, 212'si (\%12.00) 16, 283'ü (\%16.00) 17, 171'i (\%9.70) 18, 170 (\%9.60) 19, 129'u (\%7.30) 20, 89'u (\%5.00) 21, 120'si (\%6.80) 22 ve 52'si (\%2.90) 23 ve 28'i (\%1.50) 24-29 yaş aralığında yer aldığını beyan etmiştir. Öğrencilerden ise 7'si (\%.4) yaşını bildirmemiştir. Katılımcıların, 1096'sı (\%61.90) kadın, 669'u (\%37.80) erkektir. Katılımcılardan 5'i (\%.3) cinsiyetini beyan etmemiştir.

\subsection{Madde Havuzu Geliştirme Süreci}

Ölçek maddeleri hazırlanmadan önce kapsamlı bir literatür taraması yapılarak, genel bir özellik olarak yaratıcı kişilik özellikleriyle ilgili bir kuramsal temel ve madde havuzu oluşturulmaya çalışılmıştır. Alan yazın taramasında, Qian, Plucker ve Shin'ın (2010) Çin kültürüne göre yaratıcı kişilik özellikleri dağılımlarının incelediği çalışma dikkat çekmektedir. Söz konusu çalışmada dışsal faktör (Merak, deneyimlere açıklık, risk alma ve bağımsızlık), içsel faktörler (özgüven, konfirmizm, içsel motive, 1srar) ve öz faktör (öz kabul) olarak isimlendirilen üç birinci ve dokuz ikinci düzey faktör belirlenmiştir. Madde havuzu geliştirilirken diğer çalışmalarda yer alan maddeler kullanılmıştır: Kendine güven, merak ve risk alma alt boyutları, Yaratıcılı̆̆ın Değerlendirilmesi Paketi (Williams, 1980, akt. Qian vd., 2010); Konfirmizm ve 
bağımsızlık, 16 Faktörlü Kişilik Özellikleri Ölçeği (Liu, 1970, akt. Qian vd., 2010); İçsel motivasyon, Biliş İçin İhtiyaç Ölçeği (Cacioppo, Petty, Feinstein ve Jarvis, 1996, akt.Qian vd., 2010); Deneyimlere açıklık, NEO Personality Envanteri; Israr, Yaratıcı Eğilim Ölçeği (Wang, 2003, akt. Qian vd., 2010); Öz kabul, Kaliforniya Psikoloji Envanteri (Gough, 1987, akt. Qian vd., 2010) ölçme araçlarından alınmıştır. Toplamda, 130 maddeden oluşan 5'li likert tipi bir form ile 8-11 sınıf aralığında eğitimini sürdüren 1.300 öğrenciden veri toplanmıştır. Analizler sonucu, 62 maddenin çalıştığını belirlemişlerdir. Ölçeğin teknik özellikleri güvenilir ve geçerli bir araç olduğuna işaret etmektedir.

Çalışmanın yayınlandığı makalede, çalışan maddeler ve alt boyutlara göre dağılımları ek olarak verilmediği için çalışmanın detaylarına ilişkin bilgi edinilebilmesi amaciyla sorumlu yazar Qian ile e-mail yolu ile iletişime geçilmiştir. Qian ise 130 maddenin analizi sonucu, ortaya çıkan yapıyla mantıksal olarak tutarlı, madde korelasyonları en yüksek gibi özellikleri gözeten 72 maddeden seçilerek oluşturulmuş Çince bir soru havuzunu Türk örneklem grup üzerinde veri toplama amaciyla kullanılabileceğine ilişkin izin yazısı ile birlikte göndermiştir. Bunun üzerine, bu çalışmanın madde havuzunun söz konusu 72 maddeden oluşturulması kararına varılmıştır. Daha sonra, Çin Dili ve Edebiyatında görevli her iki kültürü de yakından tanıyan iki akademisyen 72 maddeden oluşan formu Çince'den Türkçeye çevirmişlerdir. Her iki çeviri sonucunda elde edilen maddeler, çevirmenlerin ve araştırmacıların bir araya gelmesiyle üzerinde uzlaşılarak Türk kültürüne özgü cümle yapıları oluşturulmuştur. Örneğin "Bence iki tarafta anlaştığında boşanılabilir, Konfüçyüs ahlak kurallarına bağlı kalmaya gerek yoktur" ifadesi "Bana göre iki tarafin onayının olması boşanmak için yeterlidir, geleneksel kurallara bağlı kalınmamalıdır." biçiminde değiştirilmiştir. Bir sonraki aşamada ise, üç farklı uzmandan (iki Türk Dili ve Edebiyatı, bir ölçme ve değerlendirme alan uzmanı) gelen görüş ve öneriler çerçevesinde ifade tarzlarını iyileştirmeye yönelik düzeltmeler yapılarak form uygulanabilir hale getirilmiştir.

\subsection{Verilerin Analizi}

Analizden önce dikkatli doldurulmayan ve uç değer olduğu belirlenen ölçekler ayıklanmıştır. Kalan ölçeklerde önce ters maddeler düzenlenmiş, sonra da eksik veriler için seri ortalamaları ataması yapılarak veriler analize hazır hale getirilmiştir. Daha sonra verilerin normallik varsayımını karşılayıp karşılamadığı incelenmiştir. ShapiroWilk testi sonucu dağılımın normal dağ̆lım özelliği sağladığı saptanmıştır ( $p>$.05).Analiz için oluşturulan veriler rassal olarak iki kısma bölünmüş, birinci grup veriler ( $\mathrm{n}=885$, kalibrasyon örneklemi) üzerinde Açımlayıcı Faktör Analizi (AFA), ikinci grup veriler ( $n=885$, çapraz geçerleme örneklemi) üzerinde ise Doğrulayıcı Faktör Analizi (DFA) gerçekleştirilmiştir. AFA ve DFA yapılırken başvurulan bu çapraz geçerleme prosedürünün amac1, bir örneklemden AFA sonucu ortaya çıan modelin, bir başka örneklemde test edilmesidir (Byrne, 1998). 


\section{BULGULAR}

Ölçeğin yapı geçerliliğinin incelenmesi üzerine öncelikli olarak AFA uygulanması kararı verilmiştir. Analizlerde, öncelikle birinci grup verilerin AFA'ya uygun olup olmadığı Kaiser-Meyer Olkin [KMO] katsayısı ve Barlett Sphericity Testine başvurularak incelenmiştir. Verilerin faktör analizine uygunluğu için KMO değerinin .60 ve üzeri ve Barlett Küresellik testinin anlamlı çıkması gerekmektedir (Büyüköztürk, 2004). Bu çalışmada, veriler faktör analizi yapmaya uygun çıkmıştır (KMO değeri, .82; Barlett Sphericty, $\chi^{2}=11257.79, p<.01$ ). Bu değerler, veri toplanan örneklemin büyüklügünün analiz için yeterli ve uygun olduğuna işaret etmektedir.

AFA işlemlerinde faktör yapılarının belirlenmesi amacıyla ilk aşamada, herhangi bir rotasyon yöntemi uygulanmaksızın, Temel Bileşenler Faktör Çıkarma Yöntemi seçilmiştir. Analiz sonucu ortaya çıkan yapılardan öz değeri 1.00 ve üzeri olanlar Yamaç-birikinti grafiği (scree plot) kırılma noktalarına göre birlikte incelendiğinde, dört faktörlü bir yapıda analizlerin sürdürülmesinin uygun olduğu kararına varılmıştır. Bu kapsamda, her bir bileşendeki maksimum varyansı ortaya çıkarabilmek için Temel bileşenler analizi dik döndürme yöntemlerinden Varimax kullanılarak yapılmıştır. Analizlerde, faktöriyel yük değerleri .30'un altında olan veya birden fazla faktör altında yer alan ve faktör yük değer farkı .10 ve daha az olan maddeler tek tek elenerek analizler yinelenmiştir. Analizler sırasında 55 döndürme işleminden sonra en sade yapıya ulaşılmıştır. Nihayetinde, 17 maddeden oluşan dört faktörlü bir yapı ortaya çıkmıştır.

Tablo 1. Yaratıcı Kişilik Özellikleri Ölçeği (YKÖÖ) Madde Faktör Yükleri

\begin{tabular}{|c|c|c|c|}
\hline Maddeler & \multicolumn{3}{|c|}{ Faktör Yükleri } \\
\hline \multicolumn{4}{|l|}{ I. Faktör: Amaç yönelimlilik } \\
\hline 1. Sadece bana etkisi olacak sorunları çözmek için uğraşırım. $\left(\mathrm{M} 68^{*}\right)^{* *}$ & \multicolumn{3}{|l|}{.75} \\
\hline $\begin{array}{l}\text { 2. Sadece problemler beni doğrudan etkilediği zaman problemler hakkında } \\
\text { düşünmeye çalışırım. (M67)** }\end{array}$ & \multicolumn{3}{|l|}{.64} \\
\hline $\begin{array}{l}\text { 3. Yeni şeyler denemeyi sadece sonucunun ne olduğunu bilmek amaciyla } \\
\text { severim. (M53) }\end{array}$ & \multicolumn{3}{|l|}{.63} \\
\hline 4. Sadece kolay olan problemler hakkında düşünmek isterim. (M39) & \multicolumn{3}{|l|}{.60} \\
\hline 5. Birşey yaparken hep aynı yolu/yöntemi izlerim. (M51) ${ }^{* *}$ & \multicolumn{3}{|l|}{.56} \\
\hline \multicolumn{4}{|l|}{ II. Faktör: İçsel motivasyon } \\
\hline 6. Yeni oyun ve etkinlikleri denemek ilgimi çeker. (M23) & \multicolumn{3}{|l|}{.67} \\
\hline 7. Bilmece türü zeka oyunları oynamayı severim. (M63) & \multicolumn{3}{|l|}{.66} \\
\hline 8. Yeni şeyler yapmayı severim. (M12) & \multicolumn{3}{|l|}{.63} \\
\hline 9. Doğal güzellikler ve sanat ilgimi çeker. (M21) & \multicolumn{3}{|l|}{.60} \\
\hline 10. Bir çok şeyi kendim denemek isterim. (M19) & .51 & & .38 \\
\hline \multicolumn{4}{|l|}{ III. Faktör: Kendine güven } \\
\hline $\begin{array}{l}\text { 11.Toplumun geneli ile kıyasladığımda kendi yeteneklerimden şüphe duyarım. } \\
(\mathrm{M} 24)^{* *}\end{array}$ & \multicolumn{3}{|c|}{.76} \\
\hline $\begin{array}{l}\text { 12. Çoğu zaman, bir çok insanın sahip olduğu yeteneklere sahip olmadığımı } \\
\text { düşünürüm. (M18)** }\end{array}$ & \multicolumn{3}{|c|}{.72} \\
\hline $\begin{array}{l}\text { 13. Daha önceden kolaylıkla başa çıkmış olduğum durumlarla karşılaştığımda } \\
\text { bile kendime güvenmem. (M11) }\end{array}$ & \multicolumn{3}{|c|}{.61} \\
\hline
\end{tabular}


Tablo 1. Yaratıcı Kişilik Özellikleri Ölçeği (YKÖÖ) Madde Faktör Yükleri (Devamı)

\begin{tabular}{ll}
\hline Maddeler & Faktör Yükleri \\
\hline IV. Faktör: Risk alma & .68 \\
14. Kuralların beni sınırlamasından hoşlanmam. (M29) & .62 \\
15. İnsanlara beklemediği sorular sormayı severim. (M31) & .58 \\
16. Bazı müzik türleri derin hayallere dalmama neden olur. (M28) & .55 \\
17. Başkalarının bilmediği şarkıları söylemeyi severim. (M35) & \\
\hline
\end{tabular}

"Uygulanan ölçekteki madde numarası, ${ }^{* *}$ Ters maddeler.

Ölçeğin madde faktör yükleri .76-.51 aralığında yer almaktadır. Alt faktörlerin açıklayabildiği varyans birinciden dördüncü alt faktöre doğru sırası ile \%16.71, \%12.91, $\% 8.97$ ve \%6.97 biçimindedir. Tüm alt faktörler birlikte toplam varyansın \%45.57'sini açılayabilmektedir.

AFA sonucu ortaya çıkan yapının örneklem verisine uyumu DFA ile sinanmıştır. DFA modeli kurulduktan sonra, ilk olarak gözlenen ve gözlenemeyen değişkenlerine ait $t$ değerleri incelenmiştir. Tüm değerlerin istatistiksel olarak anlamlı olduğu tespit edilmiştir $(p<.01)$. Daha sonra, yol katsayıları $\left(R^{2}\right)$ incelenmiştir. Maddelerin yol katsayıları .15-.67 aralığında değiştiği ve modele anlamlı olarak katkı verdiği tespit edilmiştir. DFA analizine ilişkin Path diyagramı Şekil 1'de verilmiştir.

Modelin uyum iyilik değerlerinin yükseltilebilmesi için analiz programı önerisi doğrultusunda uyarlama katsayılarına incelenmiş -önerilen hata korelasyonlarının aynı örtük değişkenlerde yer aldığının tespit edilmesi üzerine- sırasıyla M68-M67 ve M18-M24 arasında gözlenen hata varyansları serbest bırakılmıştır. Bu işlem sonrasında modelde iyileşme gözlenmiştir.

Model uyumu indeksleri ise $\chi^{2}=258.88(S d=111, p<.01)$, düzeltilmiş ki-kare $\left(\chi^{2} / S d\right)$ 2.332, Yaklaşık Hataların Ortalama Karekökü (RMSEA) .04, Standardize Edilmiş Yaklaşık Hataların Ortalama Karekökü (SRMR) .04, İyilik Uyum indeksi (GFI) .97 ve Karşılaştırmalı Uyum indeksi (CFI) .95 olarak hesaplanmıştır. DFA ile doğrulanan modelde alt boyutlar arası korelasyonların anlamlılığı da incelenmiştir.

Tablo 2. Ölçek Geneli ve Alt Faktörler Arası Korelasyon, Alt Testlerin Aritmetik Ortalama, Standart Sapma, Cronbach Alfa İç Tutarılılık Katsayısı (n= 885).

\begin{tabular}{llllll}
\hline & $\mathbf{1}$ & $\mathbf{2}$ & $\mathbf{3}$ & $\mathbf{4}$ & $\mathbf{5}$ \\
\hline 1.Amaç yönelimlilik & - & $.15^{* *}$ & $.30^{* *}$ & .05 & $.54^{* *}$ \\
2.İçsel motivasyon & & - & $.18^{* *}$ & $.26^{* *}$ & $.58^{* *}$ \\
3.Kendine güven & & & - & $.07^{*}$ & $.24^{* *}$ \\
4.Risk alma & & & & - & $.67^{* * *}$ \\
5.Genel ölçek & & & & & - \\
Aritmetik ortalama & 16.13 & 20.62 & 7.69 & 15.32 & 59.76 \\
Standart sapma & 3.59 & 2.80 & 2.62 & 2.98 & 5.91 \\
Cronbach $\alpha$ katsayis1 & .65 & .60 & .64 & .64 & .67 \\
\hline
\end{tabular}
${ }^{* * *} p<.01, " p<.05$.

Ölçekte, amaç yönelimlilik ile risk alma dişında, tüm alt faktörler ve ölçek toplamı arasında pozitif ve anlamlı korelasyonlar tespit edilmiştir $(r=.07-.67)$. Ölçek alt 
boyutlarının aritmetik ortalaması ise sirası ile $16.13 \pm 3.59,20.62 \pm 2.80,7.69 \pm 2.62$, $15.32 \pm 2.98$ ve $59.76 \pm 5.91$ olarak hesaplanmıştır. Ölçekte yer alan beş alt faktörün alt-üst dilim grup ortalamalar farkına dayalı analizi ile ölçeğin ayırt edici geçerliliği incelenmiştir. Bu yöntem uygulanırken öncelikle katılımcıların ölçek puanları büyükten küçüğe doğru sıralanmıştır. Bu sıralamaya göre 885 kişilik grubun ilk ve son \%27'lik dilimine giren 240'ar öğrencinin puanları eşleştirilmiş $t$ testi ile analiz edilmiştir.

Tablo 3. Yaratıcı Kişilik Özellikleri Alt Ölçeklerinin Üst ve Alt \%27 Gruplara Göre tTesti Sonuçları

\begin{tabular}{llllllll}
\hline & Grup & $\mathrm{N}$ & $\overline{\mathrm{X}}$ & $\mathrm{SS}$ & $\mathrm{Sd}$ & $t$ & $p^{*}$ \\
\hline Amaç yönelimlilik & Alt \%27 & 240 & 11.70 & 1.86 & 239 & -127.911 & .00 \\
& Üst \%27 & & 20.40 & 1.74 & & & \\
İçsel motivasyon & Alt \%27 & 240 & 17.07 & 1.66 & 239 & -97.235 & .00 \\
& Üst \%27 & & 23.94 & .81 & & & \\
Merak & Alt \%27 & 240 & 4.66 & 1.10 & 239 & -118.358 & .00 \\
& Üst \%27 & & 10.98 & 1.52 & & & \\
Risk alma & Alt \%27 & 240 & 11.56 & 1.93 & 239 & -81.935 & .00 \\
& Üst \%27 & & 18.82 & .85 & & & \\
Genel ölçek & Alt \%27 & 240 & 52.69 & 2.78 & 239 & -125.503 & .00 \\
& Üst \%27 & & 67.12 & 3.17 & & & \\
\hline
\end{tabular}

${ }^{*} p<.01$.

Dört alt faktör ve genel ölçek alt ve üst \%27'lik dilimlerine giren öğrenci puanları arasında anlamlı bir farklılık tespit edilmiştir $\left(t_{(240)}=-127.911,-97.235,-\right.$ 118.358, -81.935 ve $-125.503, p<.01)$. Puan farkları üst \%27'lik dilimde yer alanların lehinedir.

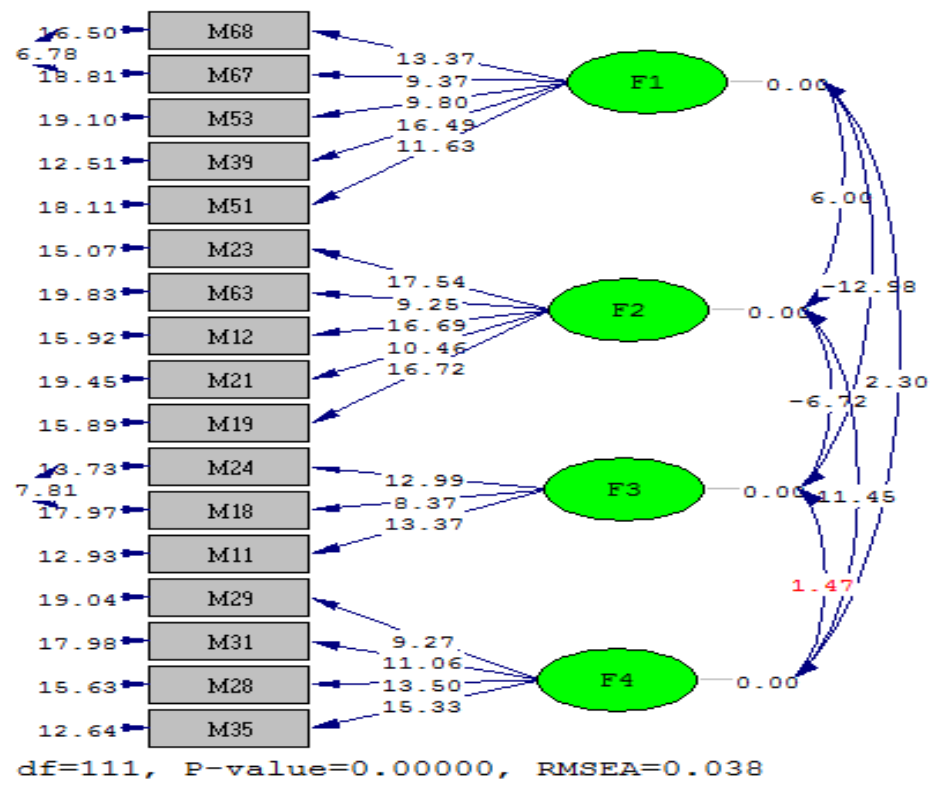

Şekil 1. YKÖÖ ilişkin Path Diyagramı ve Faktör Yükleri (F1=Amaç yönelimlilik, F2=İçsel motivasyon, F3=Merak, F4=Risk alma). 
Ölçeğin güvenilirlik değerlerinin belirlenmesi için Cronbach $\alpha$ iç tutarlılık katsayısı hesaplanmıştır. Tablo 2'den görüleceği üzere, söz konusu katsayısı ölçek toplamı .67 'dir. Alt ölçeklerden amaç yönelimlilik için iç tutarlılık katsayısı .65, içsel motivasyon için .60 , kendine güven ile risk alma için .64 olarak hesaplanmıştır. İç tutarlılık katsayısı .60-.67 aralığında değişmektedir.

\section{TARTIŞMA}

Bu çalışmada, Türk kültürüne uygun bir takım yaratıcı kişilik özelliklerinin ölçümüne yönelik bir ölçme aracı geliştirilmesi hedeflenmiştir. Bu kapsamda, lise ve üniversite öğrencilerinden oluşan bir grup öğrenci üzerinde geçerlik ve güvenilirlik çalışması yapılmıştır.

Çalışmada ölçeğin yapı geçerliliği kapsamında AFA ve DFA uygulanmıştır. AFA sonucu (KMO değeri, .815; Barlett Sphericty, $\chi^{2}=11257.790, p<.01$ ), verilerin uygun faktörler ortaya koyacağı kanaati oluşmuştur. AFA sonucu en uygun yapının belirlenebilmesi amacıyla 55 döndürme işlemi sonucu 17 maddeden oluşan dört faktörlü bir yapı saptanmıştır.

Geliştirilen ölçme aracı toplam varyansın \%45.57'sini açıklayabilmektedir. Kline'a (1994, akt. Deniz, Özer ve Işık, 2013) göre bir ölçme aracında varyansın \%40 ve üzerinde olması yapı geçerliliğinin önemli bir ölçütüdür. Bu çalışmada saptanan değer, ölçeğin faktör yapılarının güçlü olduğuna işaret etmektedir. Bunun yanı sıra, alt faktörlerin varyans oranları katılımcıların faktörlere atfettikleri öneme işaret etmektedir. Söz konusu değerler incelendiğinde, en fazla önemsenen faktörün amaç yönelimlilik olduğu belirlenmiştir. Bunu sırası ile içsel motivasyon, merak ve risk alma izlemiştir.

Hambleton'a (2005) göre bir konuyla ilgili görüş, tutum ve davranışlar kültürden kültüre veya ölçeğin geliştirildiği alt gruplara (Bryne, 2010) göre farklılaşabilmektedir. Çalışan madde sayısı ve açıklanabilen varyansa ilişkin açıklamalar birlikte değerlendirildiğinde, sözkonu farkın kültür ve/veya veri toplanan kültür ve/veya alt gruba bağlı olarak değişebileceği düşünülmüştür.

Araştırmada AFA ile ortaya atılan yapı DFA ile test edilmiştir. Model uyum indeksleri, test edilen modeli değerlendirmek için kullanılan ölçütlerdir. Farklı araştırmacılara göre farklı uyum iyilik indeksleri önerilmektedir. Bu çalışmada Kline'nın (2011) önerdiği indeksler göz önünde bulundurulmuştur. Ki-kare değeri bu göstergelerden ilkidir. Özellikle örneklemin büyük olduğu durumlarda çoğunlukla $p$ değeri anlamlılığı ile karşılaşıldığından bu değer yerine normlaştırılmış ki-kare değerine bakılması önerilmektedir (Kline, 2011). Söz konusu değerin $\leq 2.50$ olması model uyumunun iyi olduğunu (Kline, 2011), $\leq 5.00$ ise zayıf olduğunu göstermektedir (Hooper, Coughlan ve Mullen, 2008). Bu çalışmada, hesaplanan ki-kare değeri $\chi^{2}=$ $258.88(S d=111, p<.01)$, düzeltilmiş ki-kare $\left(\chi^{2} / S d\right)=2.332$ olarak saptanmıştır. Bu değerlere göre model uyumunun iyi olduğu söylenebilir.

Çalışmada Yaklaşık Hataların Ortalama Karekökü (RMSEA), Standardize Edilmiş Yaklaşık Hataların Ortalama Karekökü (SRMR), İyilik Uyum indeksi (GFI) ve 
Karşılaştırmalı Uyum indeksi (CFI) değerleri de incelenmiştir. GFI ve CFI değerlerinin $\geq .90$ olması iyi bir uyumu (Hooper, Coughlan ve Mullen, 2008; Hu ve Bentler, 1999) göstermektedir. Bu çalışmada GFI .97 ve CFI .95 olarak hesaplanmıştır. Sözkonusu göstergelere göre model uyumunun iyi düzeyde olduğu söylenebilir. RMSEA ve SRMR değerlerinin ise $\leq .05$ olması mükemmel uyum olduğuna işaret etmektedir (Hu ve Bentler, 1999). Bu çalışmada her iki değerde .04, olarak hesaplanmıştır. Söz konusu değer RMSEA ve SRMR değerlerinde mükemmel uyum olduğunu göstermektedir.

Modele ilişkin detaylı parametre analizleri için $R^{2}$ değerleri incelenmiştir. Sözkonusu değerin yüksek olması maddenin modele katkı düzeyinin yüksek olduğunun göstergesidir. Düşük olması ise tam tersine işaret eder (Kline, 2011). Bu çalışmada $R^{2}$ değerleri .15 - .67 aralığında olduğu ve her bir maddenin modele anlamlı olarak katkı verdiği belirlenmiştir. Bu sonuç, her bir maddenin modele anlamlı katkı verdiğine işaret etmektedir.

Ölçek geneli ile alt boyutlarının ayırt edici geçerliliğinin sınanması için, alt ve üst \%27'lik dilime giren puanların $t$ testi analizi yapılmıştır. Sonuçlar, ölçeğin ayırt edici geçerliliğinin sağlandığına işaret etmektedir $(p<.01)$. Ölçme aracının ayırt edici geçerliliğinin sınanması için alt boyutlar ile toplam puan arasındaki korelasyonlar da incelenmiştir. Alt ölçekler ile ölçek toplamı arasında zayıftan güçlüye değişen düzeylerde anlamlı ve pozitif korelasyonlar hesaplanmıştır ( $r=.07-.67 ; p<.01)$. Çalışmada sadece amaç yönelimlilik ile risk alma arasında anlamlı bir ilişki saptanamamıştır $(p>.01)$. Bir ölçme aracında idealinde farklı yapılar arasında orta düzeyde korelasyonlar, yapilar arasında uyumun bir göstergesi olarak değerlendirilebilir (Çokluk, Şekercioğlu ve Şener, 2012). Korelasyon sonuçları, uygun yapılar ortaya çıkmasını desteklediği söylenebilir. Amaç yönelimlilik ile risk alma arasında bir ilişkinin ortaya çıkmamış olması ise bir başka çalışmada detaylı olarak araştırılmalıdır.

Ölçeğin güvenilirliği için $\alpha$ iç tutarlılık katsayısı hesaplanmıştır. Güvenilirlik, varlıkla yokluk arasında (dichotom) bir karar durumu değildir. Bir ölçme aracının güvenilirlik değerinin .70 üzeri olması istenilir (Büyüköztürk, 2007). Ancak, .70 ve altında bir değer ortaya çıkması durumunda güvenilirliğin düşüklüğü yönünde bir yoruma varılmamalıdır (Baştürk, 2014), .60-.70 arası değerlerde kabul edilebilir düzeydedir. Çalışmada, alt faktör ve ölçek toplamının $\alpha$ değeri .60- .67 aralığında yer aldığ1 belirlenmiştir. Bu sonuçlara göre geliştirilen ölçeğin kabul edilebilir düzeyde olduğu yorumuna varılabilir.

YKÖÖ'nin geçerlik ve güvenirlik analizleri, geçerli ve güvenilir bir ölçme aracı olduğunu göstermektedir. Geliştirilen bu araç lise ve üniversite öğrencilerinin bir takım yaratıcılığı destekleyici kişilik özelliklerinin düzeyini belirleme amacıyla kullanılabilir. Çalışmada AFA ile kurulan model DFA ile doğrulanmıştır, 5'er maddeden oluşan Amaç yönelimlilik ve içsel motivasyon, 4 maddeli risk alma ve 3 maddeli Mmerak olarak isimlendirilen dört faktörlü bir yapı ortaya konulmuştur. Bu araç, araştırmacılarca veya eğitimcilerce öğrencilerin yaratıcılık düzeyini belirleme amacıyla kullanılabilir. 
Araştırmada disiplin alanlarına göre farklılaşan ve geniş bir aralıkta yer alan bir takım davranışları içeren genel yaratıcılığı destekleyici kişilik özelliklerinin ölçülmesini hedefleyen bir araç geliştirilmesi hedeflenmiştir. Ölçek geliştirme çalışmalarında sınırlı bir sürede belirli davranışlar ölçülebilmesine yönelik bir madde havuzu uygulanabilmektedir. Çalışma sonucunda Amaç yönelimlilik, içsel motivasyon, risk alma ve merak boyutları ile sınırlı bir ölçme aracı geliştirilmiştir. Dolayısıyla, bir başka çalışmada yaratıcılığı destekleyici özgüven, 1srarcılık, sebat gibi diğer kişilik özelliklerini kapsayan bir ölçek geliştirilmesi bireylerin yaratıcılıklarının daha bütünsel olarak değerlendirilmesine olanak tanıyacaktır. Bu çalışmanın bir diğer sınırlılığı veri toplanan grup ile sınırlı olmasıdır. Çalışma lise ve üniversite öğrencilerinden oluşan bir grup üzerinde gerçekleştirilmiştir. Bu sınırlılığın ortadan kaldırılabilmesi için bir başka çalışmada, orta okul öğrencileri veya yetişkin grupta geçerlik ve güvenilir bir araç geliştirilerek, gruplar karşılaştırılabilir. Konuya ilgi duyan araştırmacılar, sanat veya bilim gibi farklı alanlarda çalışan bireylerin yaratıcılığının farklılaşıp farklılaşmadığını araştırmalarının alan yazına katkı sunacaktır.

Ölçme aracından tek bir puan elde edilerek kullanılacağı gibi her bir alt faktör birbirinden bağımsız olarak da kullanılabilir. Alınabilecek en düşük ve en yüksek puanlar Amaç yönelimlilik ve içsel motivasyon 5-25, risk alma 4-20 ve merak 3-15 aralığında değişmektedir. Ölçek toplamından ise 17-85 aralığında bir puan hesaplanabilir. Uygulama formunda orijinal madde numarası 18, 24, 39, 51, 53, 67 ve 68 olan maddeler ters maddelerdir. Puanlar yükseldikçe ölçülmesi hedeflenen özelliğin yükseldiği, tam tersi durumda ise, yani puanlar düştükçe, gözlenen özelliğin daha az ortaya çıktığı biçiminde yorumlanmaktadır.

\section{KAYNAKÇA}

Aksoy, B. (2004). Coğrafya öğretiminde probleme dayalı öğrenme yaklaşımı. Yayımlanmamış doktora tezi, Gazi Üniversitesi, Ankara.

Amabile, T. M. (1983). The social psychology of creativity: A componential conceptualization. Journal of Personality and Social Psychology, 45(2), 357-376. Doi: 10.1037/0022-3514.45.2.357

Amabile, T. M. (1996). Creativity in context: Update to the social psychology of Creativity. Colarado, Boulder: Westview Press.

Bacanlı, H., İlhan, T. \& Aslan S. (2009). Beş faktör kuramına dayalı bir kişilik ölçeğinin geliştirilmesi: sıfatlara dayalı kişilik testi (SDKT). Türk Ĕ̆itim Bilimleri Dergisi, 7(2), 261-279.

Barron, F. \& Harrington, D. M. (1981). Creativity, intelligence, and personality. Annual Review Psychology, 32, 439-476.

Batey, M. \& Furnham, A. (2006). Creativity, intelligence, and personality: A critical review of the scatter literature. Genetic, social and general psychology monographs, 132(4), 355-429.

Baştürk, S. (2014). Ölçme araçlarının taşıması gereken nitelikler. Savaş, B. (Edt.), Eğitimde Ölçme ve Değerlendirme içinde (1. baskı, 23-56). Ankara: Nobel Yayıncılık.

Bryne, B. M. (2010). Structural equation modeling with AMOS: Basic concepts, applications, and programming ( $2^{\text {nd }}$ edt.). New York: Routledge Taylor \& Francis Group.

Büyüköztürk, Ş. (2004). Veri analizi el kitabı. Ankara: Pegem Yayıncılık. 
Çokluk, Ö., Şekercioğlu, G. \& Büyüköztürk, Ş. (2012). Sosyal bilimler için çok değgişkenli istatistik SPSS ve LISREL uygulamalarn (2 ${ }^{\text {nd }}$ edt) [Multivariate statistics for social sciences SPSS and LISREL applied]. Ankara: Pegem Press.

Deniz, M. E., Özer, E. \& Işık, E. (2013). Duygusal Zekâ Özelliği Ölçeği-Kısa Formu: Geçerlik ve güvenirlik çalışması. Education and Science, 38(169), 407 - 419.

Feist, G. J. (1998). A meta-analysis of personality in scientific and artistic creativity. Personality and Social Psychology Review, 2, 290-309.

Feist, G. J. (1999). Personality in scientific and artistic creativity. In R. J. Sternberg (Ed.). Handbook of human creativity, (pp. 273-296), Cambridge: Cambridge University Press.

Furnham, A. \& Bachtiar, V. (2008). Personality and intelligence as predictors of creativity. Personality and Individual Differences, 45, 613-617.

Furnham, A. Batey, M., Anand, K. \& Manfield, J. (2008). Personality, hypomania, intelligence and creativity. Personality and Individual Differences, 44, 1060-1069. Doi: 10.1016/j.paid.2007.10.035

Guilford, J. P. (1966). Measurement and creativity, Theory into Practice, 5(4), 186-202.

Hambleton, R. K. (2005). Issues, designs, and technical guidelines for adapting tests into multiple languages and cultures. In Hambleton R. K., Merenda, C. D., \& Spielberger, C. D., (Eds), Adapting educational and psychological tests for cross-cultural assessment, (pg.3-38), New Jersey: Lawrence Erlbaum Associates Publishers.

Hooper, D., Coughlan, J. \& Mullen, M. (2008). Structural equation modelling: Guidelines for determining model fit. Electronic Journal of Business Research Methods, 6(1), 53-60.

Hu, L. \& Bentler, P. M. (1999). Cutoff criteria for fit indexes in covariance structure analysis: Conventional criteria versus new alternatives. Structural Equation Modeling: A Multidisciplinary Journal, 6(1), 1-55. Doi: 10.1080/10705519909540118

Jauk, E., Benedek, M., Dunst, B. \& Neubauer, A., C. (2013). The relationship between intelligence and creativity: New support fort he threshold hypothesis by mean of empirical breakpoints detection. Intelligence, 41(4), 212-221.

Kline, R. B. (2011). Principles and practice of structural equation modeling (3 $3^{\text {rd }}$ edt.). NewYork: Guilford Press.

McCrae, R. R. \& Costa, P. T. (1997). Conceptions and correlates of openness to experience. In R. Hogan, J. A. Johnson, \& S. R. Briggs (Eds.), Handbook of personality psychology (pp. 826-848). New York: Academic Press.

Sak, U. (2016). Yaratıcılık, gelişimi ve eğitimi. (2. Baskı), Ankara: Vize yayıncılık.

Sanchez - Ruiz, M. J., Hernandez - Torrano D., Perez - Gonzalez, J. C., Batey, M. \& Petrides, K. V. (2011). The relationship between trait emotional intelligence and creativity across subject domains. Motivation and Emotion, 35(4), 461-473. Doi: 10.1007/s11031-011-9227-8

Savran, C. (1993). Sıfat listesinin (Adjective Check List) Türkiye koşullarına uygun dilsel eşdeğerlilik, geçerlik, güvenirlik ve norm çalışması ve örnek uygulama (Yayımlanmamış Doktora Tezi), M.Ü. Sosyal Bilimler Enstitüsü Eğitim Bilimleri, İstanbul.

Soldz, S. \& Vaillant, G. E. (1999). The big five personality traits and the life course: A 45- year longitudinal study. Journal of Research in Personality, 33(2), 208-232. 
Sternberg, R. J. \& Lubart, T. I. (1991). An investment theory of creativity and its development. Human Development, 34, 1-32.

Sternberg, R. J., O'Hara, L. A. \& Lubart, T. I. (1997). Creativity as investment. California Management Review, 40(1), 8-21.

Sternberg, R. J., Jarvin, L. \& Grigorenko, E. L. (2011). Explorations in giftedness. NewYork: Cambridge University Press.

Şahin, F. (2016). Kaufman Alanları Yaratıcılık Ölçeği'nin Türkçeye uyarlanması ve psikometrik özelliklerinin incelenmesi. İlköğretim Online, 15(3), 855-867. Doi: 10.17051/io.2016.70479.

Şahin, F. \& Şahin, D. (2012). Engelli bireylerle çalışan özel eğitim öğretmenlerinin tükenmişlik düzeyinin belirlenmesi, Öğretmen Eğitimi ve Eğitimcileri Dergisi, 2(1), 275-294.

Şahin, F. \& Şahin, D. (2013). Bilim ve sanat merkezinde çalışan öğretmenlerin tükenmişlik düzeyi. Üstün Yeteneklilerin Eğitimi Araştırmaları Dergisi, 1 (2), Özel sayı, 51-66.

Qian, M., Plucker, J. M. \& Shen, J. (2010). A Model of Chinese Adolescents' Creative Personality, Creativity Research Journal, 22(1), 62-67, Doi: 10.1080/10400410903579585

Terreffinger, D. J., Young, G. C., Selby, E., C. \& Shepardson, C. (2002). Assessing creativity: A guide for educators. Center for Creative Learning Sarasota, Florida (RM02170). 


\section{EK}

\section{Yaratıcı Kişilik Özellikleri Ölçeği (YKÖÖ)}

$\mathrm{Bu}$ çalışma kişisel özelliklerinizi anlamanıza yardımcı olmak için hazırlanmıştır. Okuduğunuz her cümle için, düşüncenize en uygun olduğunu düşündüğünüz seçeneğe " $X$ " işareti koyunuz. Örnek olarak, okuduğunuz cümledeki ifadeye kesinlikle katılmıyorsanız, cevap kısmındaki ilk kolona " $X$ " işareti koyunuz. Eğer belirtilen ifadeye bazen katılıyorsanız, ikinci kolona " $X$ " işareti koyunuz, ve diğer kolonlar için aynı şekilde fikrinizi belirtiniz.

\begin{tabular}{|c|c|c|c|c|c|}
\hline Maddeler & 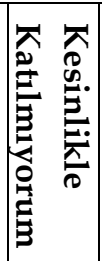 & 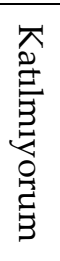 & 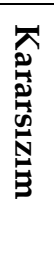 & 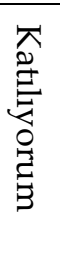 & 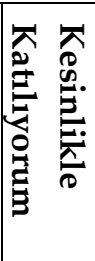 \\
\hline 1.Sadece bana etkisi olacak sorunları çözmek için uğraşırım.* & 1 & 2 & 3 & 4 & 5 \\
\hline $\begin{array}{l}\text { 2.Sadece problemler beni doğrudan etkilediği zaman problemler } \\
\text { hakkında düşünmeye çalışırım.* }\end{array}$ & 1 & 2 & 3 & 4 & 5 \\
\hline $\begin{array}{l}\text { 3.Yeni şeyler denemeyi sadece sonucunun ne olduğunu bilmek } \\
\text { amacıyla severim* }\end{array}$ & 1 & 2 & 3 & 4 & 5 \\
\hline 4.Sadece kolay olan problemler hakkında düşünmek isterim. ${ }^{*}$ & 1 & 2 & 3 & 4 & 5 \\
\hline 5.Birşey yaparken hep aynı yolu/yöntemi izlerim. ${ }^{*}$ & 1 & 2 & 3 & 4 & 5 \\
\hline 6.Yeni oyun ve etkinlikleri denemek ilgimi çeker. & 1 & 2 & 3 & 4 & 5 \\
\hline 7. Bilmece türü zeka oyunları oynamayı severim & 1 & 2 & 3 & 4 & 5 \\
\hline 8. Yeni şeyler yapmayı severim. & 1 & 2 & 3 & 4 & 5 \\
\hline 9. Doğal güzellikler ve sanat ilgimi çeker. & 1 & 2 & 3 & 4 & 5 \\
\hline 10.Bir çok şeyi kendim denemek isterim. & 1 & 2 & 3 & 4 & 5 \\
\hline $\begin{array}{l}\text { 11.Toplumun geneli ile kıyasladığımda kendi yeteneklerimden } \\
\text { şüphe duyarım.* }\end{array}$ & 1 & 2 & 3 & 4 & 5 \\
\hline $\begin{array}{l}\text { 12.Çoğu zaman, bir çok insanın sahip olduğu yeteneklere sahip } \\
\text { olmadığımı düşünürüm.* }\end{array}$ & 1 & 2 & 3 & 4 & 5 \\
\hline $\begin{array}{l}\text { 13.Daha önceden kolaylıkla başa çıkmış olduğum durumlarla } \\
\text { karşılaştığımda bile kendime güvenmem.* }\end{array}$ & 1 & 2 & 3 & 4 & 5 \\
\hline 14.Kuralların beni sınırlamasından hoşlanmam. & 1 & 2 & 3 & 4 & 5 \\
\hline 15.İnsanlara beklemediği sorular sormayı severim. & 1 & 2 & 3 & 4 & 5 \\
\hline 16.Bazı müzik türleri derin hayallere dalmama neden olur. & 1 & 2 & 3 & 4 & 5 \\
\hline 17.Başkalarının bilmediği şarkıları söylemeyi severim. & 1 & 2 & 3 & 4 & 5 \\
\hline
\end{tabular}

*Ters olarak puanlanması gereken maddeler. 